\title{
Optimization of fermentation media and growth conditions for microbial xylanase production
}

\author{
Bushra Kalim $^{1} \cdot$ Nazish Mazhar Ali ${ }^{1}$
}

Received: 21 March 2016/ Accepted: 25 May 2016/Published online: 3 June 2016

(c) The Author(s) 2016. This article is published with open access at Springerlink.com

\begin{abstract}
Efficiency of cellulase-free xylanases is one of the determining factors in paper and pulp industries. Use of microbes which can produce cellulase-free xylanases may help to overcome the current challenges in kraft pulp processing. Isolation and screening of microorganisms from local samples offers a possibility for obtaining the potential microbes for this purpose. This research was therefore aimed to collect, screen, characterize and identify potential cellulase-free xylanase producers. A total of 313 microbial isolates were collected while using selective media (EBAM and XAM) to determine the xylanolytic potential of microbes. Qualitative and quantitative analyses were performed and finally 11 bacterial and 6 fungal strains were selected for characterization and identification. The potential isolates were identified as Bacillus pumilus (388.82 U/mg), Bacillus safensis (385.26 U/mg), Aspergillus flavus (493.33 U/mg) and Aspergillus niger (419.33 U/mg). Optimization of the microbial strains while using agro-industrial waste is suggested.
\end{abstract}

Keywords Xylanase $\cdot$ Characterization $\cdot$ Xylanolytic microbes $\cdot$ Enzymatic activity

\section{Introduction}

Xylanases are of great importance in a number of industrial processes and the increasing trend towards an environment friendly industrialization has paved its ways.

Nazish Mazhar Ali

nazipak@hotmail.com

1 Microbiology Laboratory, Department of Zoology, GCU, Lahore, Pakistan
Hemicelluloses, being the second most abundant component of plant biomass tend to be suitable agro-industrial residue (Collins et al. 2005). 20-35\% of the total dry mass of plants constitutes xylans which are useful as fermentation substrate for the production of sugars and biofuel (Haltrich et al. 1996; Filho 1998). Xylans are heterogeneous compounds and require synergistic reaction of hydrolytic enzymes for their complete degradation. Among these enzymes, endo- $\beta-1,4-x y l a n a s e s$ (EC.3.2.1.8) are the most important xylanolytic enzymes which cleave off the internal glycosidic bonds in xylan backbone, reducing the degree of polymerization (Biely 1985; Polizeli et al. 2005). The cleavage carried out by these enzymes is very specific and the degree of substitution in the polymer affects the hydrolysis product (Dodd and Cann 2009).Interest in the xylanolytic enzymes has received much attention due to their potential uses in different industrial processes such as kraft pulp bleaching, biopulping in paper and pulp industry, in animal feed stock, bread and beverages (Kirk and Yang 1979; Schwien and Schmidt 1982; Viikari et al. 1986; Madlala et al. 2001).

Some marine algae are also reported to secrete xylanases in extracellular environment (Polizeli et al. 2005). Xylanases of protozoan and crustacean origin are also reported (Devillard et al. 1999; Polizeli et al. 2005). Unusual xylanases from the gut of insects have been studied (Roy et al. 2003; Brennan et al. 2004). Wu and He (2015) have recently reported isolation of a xylanolytic strain Cellvibrio mixtus from giant snail in Singapore whereas similar reports of xylanases from fresh water mollusc have been noted from Yamura (Yamura et al. 1997). Many microbial sources including bacteria, fungi and yeast are being reported with tolerable temperature and $\mathrm{pH}$ ranges (Sunna and Antranikian 1997). Filamentous fungi, especially from Aspergillus and Trichoderma spp. are reported to be the 
best sources of xylanases with higher levels of extracellular xylanase production (Haltrich et al. 1996).

To contribute in the improvement of biodegradation of hemicelluloses through microbial co-cultures, exploration, selection and characterization of potential cellulase-free xylanase producing microbes may have important roles. The production of cellulase-free xylanase is of crucial importance in paper and pulp industry. Thus, the objective of the present study was to collect, screen, identify and characterize cellulase-free xylanase producing locally isolated microbial strains.

\section{Materials and methods}

\section{Sample collection and microbial isolation}

Samples for isolation of xylanase producing bacteria and fungi were obtained from particular sites. Samples of soil, leaf compost, grazer dunks and paper industry waste were put into plastic bags. Fresh ruminal fluids were collected from local slaughter houses and after filtration through a muslin cloth stored at $4{ }^{\circ} \mathrm{C}$ until further use.

To isolate bacteria and fungi from soil and litter, $1 \mathrm{~g}$ of each crushed-sample and $1 \mathrm{ml}$ of ruminal sample were suspended in $100 \mathrm{ml}$ of sterile water by vortexing. Using standard spread plate technique, $100 \mu$ of each sample suspension was spread onto the surface of nutrient agar plates supplemented with $15 \mathrm{ppm}$ cycloheximide to isolate bacterial strains. For the isolation of fungal strains, $1 \mathrm{ml}$ of each suspension was spread on YpSs agar plates supplemented with $0.08 \%$ streptomycin. All plates were incubated overnight at $37{ }^{\circ} \mathrm{C}$ (for bacteria) and at $28{ }^{\circ} \mathrm{C}$ for 3-4 days (for fungi). Based on their appearance and morphology, various colonies were selected to obtain pure cultures on NA and PDA plates for bacterial and fungal isolates, respectively.

\section{Screening of xylanase producing bacterial}

Two step screening assay was used to determine the xylanase producing potential of the microbial strains. For the initial screening of lignocelluloses hydrolytic enzyme production, the isolates were grown on wheat bran agar medium (Composition: $\mathrm{g} / \mathrm{L}$; wheat bran powder_50.0, peptone_10.0, phosphate buffer_2 $\mathrm{ml}$, agar_20.0) plates to limit the number of isolates for screening assay. All purified strains were spot tested by incubating them for 2-3 days at $28{ }^{\circ} \mathrm{C}$ on WBA plates. Strains showing significant growth on WBA were selected for xylanase screening assays. To detect the xylanase production ability, microbial strains were inoculated on $0.1 \%$ xylan agar medium (Composition: g/L; yeast extract_3.0, peptone_1.5, $\quad \mathrm{NaCl} \_3.5, \quad \mathrm{NaNO}_{3} \_1.0, \quad \mathrm{KH}_{2} \mathrm{PO}_{4} \_1.0$, $\mathrm{MgSO}_{4} \cdot 7 \mathrm{H}_{2} \mathrm{O} \_0.3$ Agar_20 and $0.1 \%$ beechwood xylan) plates ( $\mathrm{pH} 5.5)$. Plates were incubated at $28^{\circ} \mathrm{C} \pm 2$ for $72 \mathrm{~h}$. All the plates were stained with $0.5 \%$ Congo red dye for about half an hour and were then destained using $1 \mathrm{M}$ $\mathrm{NaCl}$ solution at room temperature. Zones of clearance were observed for presence of xylanase activity. Microbes showing positive results were selected for further analysis.

\section{Xylanase production in submerged fermentation}

Xylanase activities of the selected isolates were measured using 3, 5-dinitrosalicylic acid (DNS) method (Ghose 1987) for determination of the amount of reducing sugars released during certain times of reaction mixture. Prior to xylanase assay, both the bacterial and fungal isolates were cultured in xylan broth medium (XBM) under submerged fermentation conditions (Samantha et al. 2011). For that purpose, $50 \mathrm{ml} \mathrm{XBM}$ (Composition: $\mathrm{g} / \mathrm{L}$; yeast extract_5.0, peptone_1.0, $\mathrm{NaNO}_{3} \_$1.0, $\quad \mathrm{KH}_{2} \mathrm{PO}_{4}{ }_{1} .0, \quad \mathrm{MgSO}_{4} \cdot 7 \mathrm{H}_{2} \mathrm{O} \_0.02$, xylan_10.0) (pH 5.5) was prepared in $250 \mathrm{~mL}$ flask for each microbial strain separately. Medium was autoclaved at $121{ }^{\circ} \mathrm{C}, 15 \mathrm{lb}$ for $15 \mathrm{~min}$. Each strain was inoculated in separate flask and, flasks were incubated in a shaking incubator at $31 \pm 2{ }^{\circ} \mathrm{C}$ for 7 days.

After 7 days of incubation, crude enzyme was extracted by filtration and the filtrate was centrifuged at 10,000 rpm for $20 \mathrm{~min}$ at $4{ }^{\circ} \mathrm{C}$. The cell free culture filtrate (CFCF) was used as crude enzyme. Afterwards, the enzyme extract was filtered through $0.45 \mu \mathrm{m}$ microfilter membranes to make it free of cellular mass. Pellets were oven dried at $70{ }^{\circ} \mathrm{C}$ overnight and weighed to record biomass.

\section{Well plate diffusion assay}

Well plate diffusion assay was performed to qualitatively analyze enzyme activity. Xylan agar medium (Composition: g/L; xylan_9.0,agar_20.0,0.1 M phosphate buffer_to raise volume upto $1000 \mathrm{ml}$ ) prepared in phosphate buffer (pH 5.5) was autoclaved for $15 \mathrm{~min}$ at $121{ }^{\circ} \mathrm{C}$ and $15 \mathrm{lb}$ (Samantha et al. 2011). Medium was poured in each disposable petri plate and was allowed to solidify. Upon solidification, wells were made by using sterilized cork borer of $10 \mathrm{~mm}$ diameter. To each well, $100 \mu \mathrm{l}$ of the CFCF was poured and incubated at $31{ }^{\circ} \mathrm{C}$ overnight. To compare the effect of endo-xylanase by simple diffusion and Congo red assay, zones of clearance produced in incubated plates were recorded before and after being stained with $0.5 \%$ Congo red dye for $30 \mathrm{~min}$. Afterwards, stained plates were flooded with $1 \mathrm{M} \mathrm{NaCl}$ for destaining. Here, appearance of clear zones confirmed the presence of 1-4- $\beta$-endo-xylanase activity. 


\section{Xylanase assay}

Xylanase assay was measured according to Bailey et al. (1992). CFCF was used as crude enzyme and $300 \mu \mathrm{l}$ was incubated with $700 \mu \mathrm{l}$ of $1 \%$ solubilized birchwood xylan solution at $50{ }^{\circ} \mathrm{C}$ for $30 \mathrm{~min}$ in shaking incubator. Reaction was stopped by adding $1.5 \mathrm{~mL}$ of DNS reagent and was then boiled for $10 \mathrm{~min}$. Reaction mixture was allowed to cool to room temperature. Afterwards, all samples were centrifuged at $10,000 \mathrm{rpm}$ for $5 \mathrm{~min}$ at $4{ }^{\circ} \mathrm{C}$ to free the reaction mixture of cell debris. Afterwards, OD was recorded at $540 \mathrm{~nm}$. The xylanase activity was expressed as $\mathrm{mg} / \mathrm{mL}$ by comparing with standard curve of xylose prepared while using 0-500 $\mu \mathrm{g}$ xylose.

\section{Cellulase activity}

Cellulase activity was measured according to Ghose (1987). Seven hundred $\mu 1$ of $1 \%$ carboxymethyl cellulose was incubated with $300 \mu \mathrm{l}$ of CFCF. To stop the reaction, $1.5 \mathrm{ml}$ of DNS reagent was added and boiled the reaction mixture for $10 \mathrm{~min}$. After filtration, absorbance was measured at $540 \mathrm{~nm}$. CMCase activity was expressed in $\mathrm{mg} /$ $\mathrm{mL}$ by comparing it with glucose standard curve prepared using $0-500 \mu \mathrm{g}$ glucose.

\section{$\beta$-Xylosidase activity}

The activity of $\beta$-xylosidase was estimated by Lachke's method. Substrate selected for xylosidase activity was $4 \mathrm{mM}$ solution of $\rho$-nitrophenyl- $\beta$-D-xylopyranoside ( $\rho$-NPX). Nine hundred $\mu \mathrm{L}$ of $\rho-\mathrm{NPX}$ substrate along with $100 \mu \mathrm{L}$ of cell free culture filtrate was incubated at $50{ }^{\circ} \mathrm{C}$ for $30 \mathrm{~min}$. Afterwards, $1 \mathrm{~mL}$ of $2 \mathrm{M}$ sodium carbonate solution was added and absorbance was recorded at $410 \mathrm{~nm}$. Standard curve of $\rho$-nitrophenol was used for comparison.

\section{Determination of total protein content}

Bradford's assay was used for total protein estimation. 1 $\mathrm{mL}$ of enzyme extract was taken in a glass tube and $3 \mathrm{~mL}$ of Bradford's reagent was added to it. This mixture was incubated at room temperature for 5-10 min. Afterwards, OD was measured at $595 \mathrm{~nm}$ and compared against Bovine
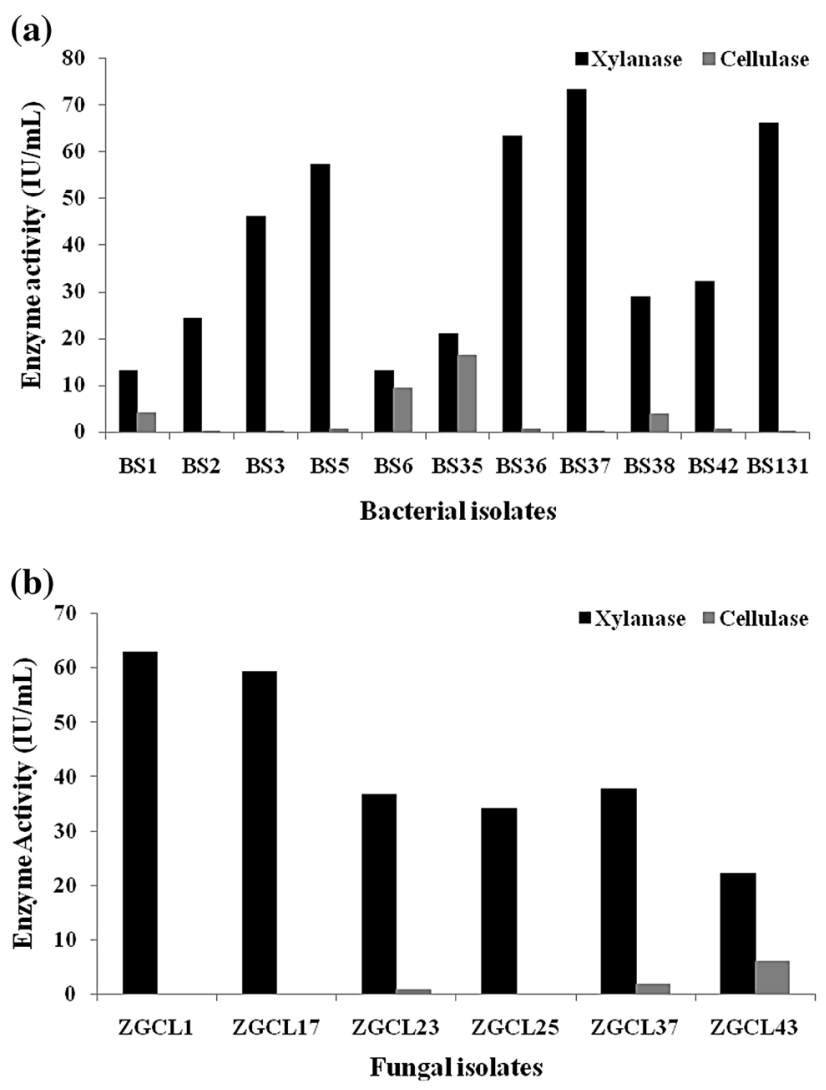

Fig. 2 Xylanolytic and cellulolytic indexes of $\mathbf{a}$ bacterial and $\mathbf{b}$ fungal isolates
Fig. 1 Screening of xylanolytic microbes $\mathbf{a}$ before and $\mathbf{b}$ after Congo red staining
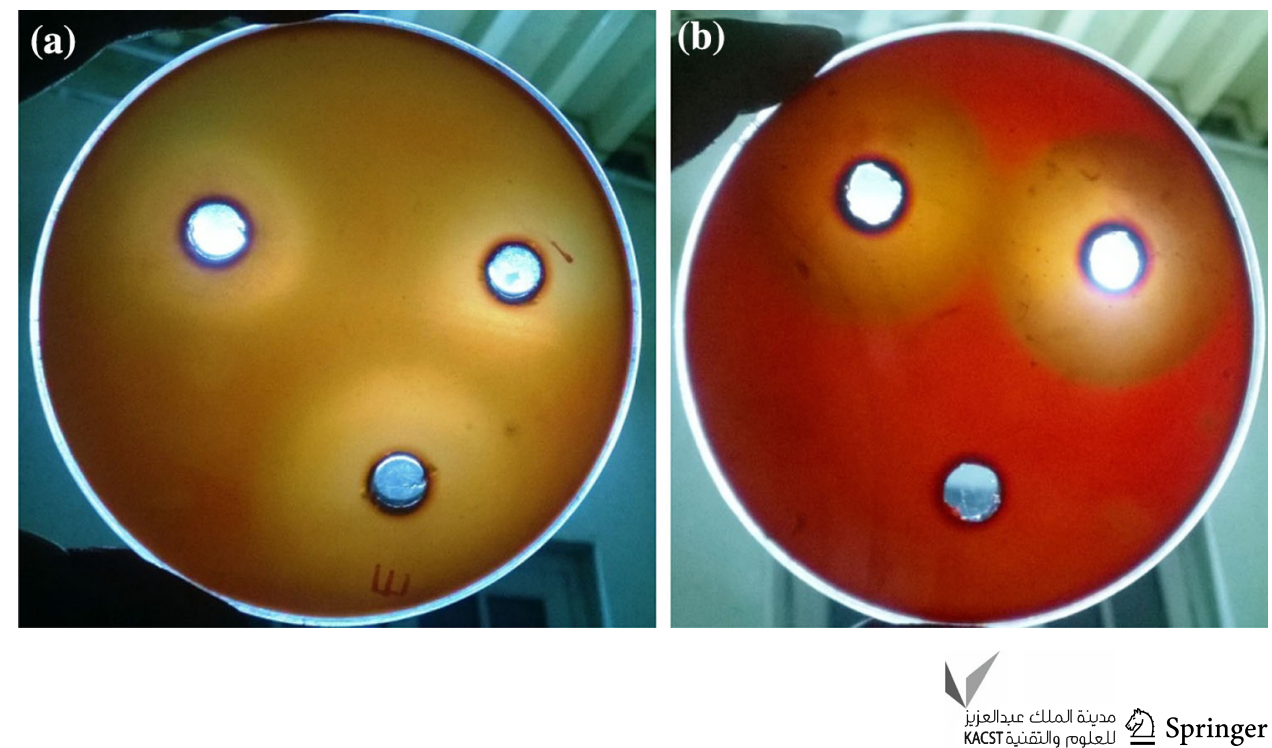
Table 1 Qualitative and quantitative analysis of the extracellular enzyme produced by bacterial isolates

\begin{tabular}{|c|c|c|c|c|c|c|c|c|c|c|c|c|c|c|}
\hline \multirow[t]{3}{*}{ Sr. no. } & \multirow[t]{3}{*}{$\begin{array}{l}\text { Bacterial } \\
\text { strain }\end{array}$} & \multicolumn{6}{|c|}{$\begin{array}{l}\text { Diameter of zone of } \\
\text { clearance }(\mathrm{mm}) \text { at different } \\
\mathrm{pH}\end{array}$} & \multirow[t]{3}{*}{$\begin{array}{l}\text { Dry weight } \\
(\mathrm{mg})\end{array}$} & \multicolumn{4}{|c|}{ Enzyme activity (IU/mL) } & \multirow[t]{3}{*}{$\begin{array}{l}\text { Total protein } \\
(\mathrm{mg} / \mathrm{mL})\end{array}$} & \multirow{3}{*}{$\begin{array}{l}\text { Specific activity } \\
\text { (IU/mg) } \\
\text { Endo-xylanase }\end{array}$} \\
\hline & & \multicolumn{3}{|c|}{$\begin{array}{l}\text { Simple } \\
\text { diffusion }\end{array}$} & \multicolumn{3}{|c|}{$\begin{array}{l}\text { Congo red } \\
\text { assay }\end{array}$} & & \multirow[t]{2}{*}{ Endoxylanase } & \multirow[t]{2}{*}{$\mathrm{CM}$ case } & \multirow[t]{2}{*}{ FPase } & \multirow[t]{2}{*}{$\beta$-Xylosidase } & & \\
\hline & & 4.5 & 5.5 & 6.5 & 4.5 & 5.5 & 6.5 & & & & & & & \\
\hline 1 & BS131 & 32 & 30 & 30 & 32 & 30 & 31 & 1.7 & 66.1 & 0.01 & 0.43 & 8.12 & 0.17 & 388.82 \\
\hline 2 & BS37 & 31 & 29 & 31 & 31 & 29 & 31 & 2.1 & 73.2 & 0.06 & 0.04 & 5.12 & 0.19 & 385.26 \\
\hline 3 & BS3 & 25 & 24 & 22 & 25 & 26 & 22 & 1.1 & 46.1 & 0.02 & 0.34 & 5.18 & 0.13 & 354.17 \\
\hline 4 & BS2 & 19 & 23 & 20 & 21 & 23 & 22 & 1.2 & 24.4 & 0.09 & 0.63 & 9.12 & 0.07 & 348.57 \\
\hline 5 & BS5 & 19 & 20 & 24 & 19 & 20 & 25 & 3.2 & 57.3 & 0.49 & 0.31 & 8.17 & 0.19 & 301.58 \\
\hline 6 & BS42 & 21 & 19 & 20 & 21 & 19 & 22 & 4.5 & 32.2 & 0.38 & 0.09 & 8.34 & 0.11 & 292.73 \\
\hline 7 & BS1 & 18 & 17 & 21 & 18 & 19 & 23 & 1.3 & 13.3 & 3.92 & 11.2 & 15.8 & 0.05 & 266.00 \\
\hline 8 & BS38 & 19 & 18 & 22 & 21 & 18 & 22 & 2.4 & 29.1 & 3.63 & 3.51 & 6.26 & 0.11 & 264.55 \\
\hline 9 & BS36 & 17 & 19 & 16 & 17 & 19 & 17 & 2.1 & 63.3 & 0.44 & 0.13 & 7.35 & 0.27 & 234.44 \\
\hline 10 & BS6 & 19 & 16 & 21 & 19 & 16 & 21 & 1.3 & 13.2 & 9.21 & 7.21 & 3.35 & 0.06 & 220.00 \\
\hline 11 & BS35 & 15 & 21 & 22 & 15 & 20 & 22 & 2.7 & 21.2 & 16.2 & 19.3 & 2.63 & 0.11 & 192.73 \\
\hline 12 & BS73 & 11 & 11 & 10 & 11 & 11 & 10 & 1.3 & 8.45 & 7.46 & 11.3 & 10.7 & 0.07 & 120.71 \\
\hline 13 & BS92 & 11 & 12 & 10 & 11 & 11 & 09 & 2.2 & 5.13 & 9.17 & 13.2 & 5.78 & 0.06 & 85.50 \\
\hline 14 & BS123 & 09 & 08 & 09 & 09 & 08 & 09 & 1.1 & 7.91 & 8.43 & 9.18 & 9.33 & 0.13 & 60.851 \\
\hline 15 & BS27 & 07 & 09 & 09 & 07 & 09 & 08 & 1.5 & 9.52 & 6.74 & 9.13 & 8.77 & 0.17 & 56.00 \\
\hline 16 & BS65 & 07 & 07 & 08 & 07 & 07 & 08 & 2.1 & 11.8 & 9.91 & 13.2 & 5.83 & 0.23 & 51.300 \\
\hline 17 & BS78 & 05 & 05 & 06 & 05 & 05 & 07 & 1.5 & 3.52 & 14.1 & 13.8 & 15.4 & 0.09 & 39.11 \\
\hline 18 & BS99 & 06 & 05 & 06 & 06 & 05 & 07 & 2.1 & 4.94 & 8.32 & 9.87 & 11.9 & 0.16 & 30.88 \\
\hline
\end{tabular}

serum albumin (BSA) standard curve. Specific activity was calculated with the help of formula.

Specific activity $(\mathrm{IU} / \mathrm{mg})=\frac{\text { Enzyme activity }(\mathrm{IU})}{\text { Protein content }(\mathrm{mg})}$

\section{Phenotypic characterization of competent xylanolytic microbes}

\section{Molecular characterization}

Potential xylanase producing microbial strains were identified on the basis of morphological, cultural, biochemical properties and ribotyping of conserved sequences. Molecular characterization of the best xylanase producing microbes was carried out to identify potential bacterial and fungal strains. Bacterial genomic DNA was extracted using phenol-chloroform extraction protocol (Sambrook and Russell 2001) whereas for fungal genomic DNA extraction, CTAB method was used. Afterwards, PCR amplification for the conserved sequences of DNA was performed and the amplified gene product was sequenced.

Molecular characterization of bacterial strains was carried out by amplifying $16 \mathrm{~S}$ ribosomal RNA gene. Universal $16 \mathrm{~S}$ rDNA primers were selected for gene amplification.
27F (5'-AGAGTTTGATCMTGGCTCAG-3') and 1492R (5'-TACGGYTACCTTGTTACGACTT-3') (Frank et al. 2008). Fungal rDNA ITS region was amplified while using ITS1 (5'-TCCGTAGGTGAACCTGCGG-3') and ITS4 (5'TCCTCCGCTTATTGATATGC-3') (Fujita et al. 2001).

\section{Results}

\section{Isolation and screening of xylanolytic strains}

From all collected samples, a total of 184 microbial isolates were selected after primary screening on WBA medium. Out of these 184 isolates, 133 bacterial and 51 fungal strains were selected for secondary screening. Sixty-one bacterial and 27 fungal strains showed positive results to qualitative test of xylanase as indicated by the formation of clear zones in xylan agar medium plates.

\section{Xylanase production in $\mathrm{SmF}$}

The selected strains with clear zones in xylan agar plates were further subjected to enzyme diffusion technique for qualitative analysis of extracellular 1,4- $\beta$-endoxylanase 
Table 2 Qualitative and quantitative analysis of the extracellular enzyme produced by fungal isolates

\begin{tabular}{|c|c|c|c|c|c|c|c|c|c|c|c|c|c|c|}
\hline \multirow[t]{3}{*}{ Sr. no. } & \multirow[t]{3}{*}{$\begin{array}{l}\text { Fungal } \\
\text { strain }\end{array}$} & \multicolumn{6}{|c|}{$\begin{array}{l}\text { Diameter of zone of } \\
\text { clearance }(\mathrm{mm}) \text { at different } \\
\mathrm{pH}\end{array}$} & \multirow[t]{3}{*}{$\begin{array}{l}\text { Dry weight } \\
\text { (mg) }\end{array}$} & \multicolumn{4}{|c|}{ Enzyme activity (IU/mL) } & \multirow[t]{3}{*}{$\begin{array}{l}\text { Total protein } \\
(\mathrm{mg} / \mathrm{mL})\end{array}$} & \multirow{3}{*}{$\begin{array}{l}\text { Specific activity } \\
\text { (IU/mg) } \\
\text { Endo-xylanase }\end{array}$} \\
\hline & & \multicolumn{3}{|c|}{$\begin{array}{l}\text { Simple } \\
\text { diffusion }\end{array}$} & \multicolumn{3}{|c|}{$\begin{array}{l}\text { Congo red } \\
\text { assay }\end{array}$} & & \multirow[t]{2}{*}{ Endoxylanase } & \multirow[t]{2}{*}{ CM case } & \multirow[t]{2}{*}{ FPase } & \multirow[t]{2}{*}{$\beta$-Xylosidase } & & \\
\hline & & 4.5 & 5.5 & 6.5 & 4.5 & 5.5 & 6.5 & & & & & & & \\
\hline 1 & ZGCL17 & 35 & 37 & 41 & 35 & 37 & 41 & 3.8 & 59.2 & 0.06 & 0.03 & 15.2 & 0.12 & 493.33 \\
\hline 2 & ZGCL1 & 38 & 35 & 37 & 39 & 36 & 37 & 5.4 & 62.9 & 0.01 & 0.05 & 9.13 & 0.15 & 419.33 \\
\hline 3 & ZGCL25 & 36 & 38 & 36 & 36 & 38 & 37 & 4.7 & 34.1 & 0.03 & 0.04 & 27.5 & 0.11 & 391.82 \\
\hline 4 & ZGCL37 & 29 & 26 & 31 & 30 & 26 & 31 & 3.9 & 37.7 & 1.81 & 3.72 & 18.72 & 0.12 & 284.16 \\
\hline 5 & ZGCL23 & 24 & 26 & 25 & 23 & 26 & 26 & 7.6 & 36.7 & 0.89 & 1.61 & 7.91 & 0.21 & 174.76 \\
\hline 6 & ZGCL43 & 18 & 18 & 15 & 18 & 19 & 15 & 4.2 & 22.2 & 5.94 & 7.54 & 3.21 & 0.13 & 170.77 \\
\hline 7 & ZGCL12 & 16 & 19 & 17 & 16 & 18 & 17 & 8.2 & 27.3 & 7.63 & 8.71 & 9.21 & 0.17 & 160.58 \\
\hline 8 & ZGCL15 & 11 & 10 & 13 & 11 & 13 & 13 & 9.7 & 29.8 & 2.32 & 4.83 & 9.12 & 0.19 & 156.84 \\
\hline 9 & ZGCL49 & 10 & 10 & 11 & 10 & 12 & 11 & 4.1 & 20.1 & 11.2 & 9.91 & 7.45 & 0.14 & 143.57 \\
\hline 10 & ZGCL33 & 13 & 11 & 12 & 13 & 11 & 12 & 9.3 & 18.9 & 13.2 & 17.2 & 11.2 & 0.19 & 99.47 \\
\hline 11 & ZGCL22 & 09 & 10 & 08 & 10 & 13 & 10 & 4.7 & 13.2 & 21.2 & 12.3 & 23.3 & 0.15 & 88.00 \\
\hline 12 & ZGCL11 & 11 & 08 & 12 & 11 & 08 & 11 & 11.3 & 19.9 & 11.9 & 13.4 & 5.18 & 0.32 & 62.19 \\
\hline 13 & ZGCL3 & 07 & 09 & 08 & 07 & 11 & 10 & 9.2 & 18.9 & 19.7 & 11.8 & 19.3 & 0.29 & 65.17 \\
\hline 14 & ZGCL41 & 07 & 08 & 10 & 07 & 10 & 10 & 12.1 & 11.9 & 17.6 & 9.31 & 19.7 & 0.32 & 37.19 \\
\hline 15 & ZGCL4 & 05 & 07 & 07 & 06 & 07 & 07 & 16.1 & 33.9 & 16.4 & 11.3 & 2.87 & 1.1 & 30.82 \\
\hline
\end{tabular}

Table 3 Morphological Identification of potential xylanase producing microbes

\begin{tabular}{lll}
\hline Fungal strain & Isolation source & Identified as \\
\hline ZGCL1 & Soil & Aspergillus sp. \\
ZGCL17 & Soil & Aspergillus sp. \\
ZGCL23 & Saw dust & Fusarium sp. \\
ZGCL25 & Soil & Penicillium sp. \\
ZGCL37 & Decaying wood & Trichoderma sp. \\
ZGCL43 & Soil & Aspergillus sp. \\
BS1 & Ruminal fluid (Goat) & Bacillus sp. \\
BS2 & Decaying cow dung & Bacillus sp. \\
BS3 & Leaf compost & Bacillus sp. \\
BS5 & River bank soil & Providencia sp. \\
BS6 & Paper mill effluent & Bacillus sp. \\
BS35 & Raw milk & Staphylococcus sp. \\
BS36 & Moist soil & Bacillus sp. \\
BS37 & Moist soil & Bacillus sp. \\
BS38 & Decaying agro-waste & Bacillus sp. \\
BS42 & Leaf compost & Bacillus sp. \\
BS131 & Moist soil & Bacillus sp. \\
\hline
\end{tabular}

production under submerged fermentation while using XBM. Cell free culture filtrate on incubation produced clear zones visible against opaque xylan intact agar in the medium. Zones of clearance were recorded before and after Congo red staining. Results were more or less the same as recorded before staining (Tables 2, 3). 
Table 4 Identification of potential xylanase producing bacteria based on 16S ribosomal RNA gene sequence

\begin{tabular}{|c|c|c|c|c|c|}
\hline Sr. no. & Bacterial strain & Isolation source & Identified as & Similarity $(\%)$ & NCBI Accession no. \\
\hline 1 & BS1 & Ruminal fluid (Goat) & Bacillus cereus & 100 & КT356279 \\
\hline 2 & BS2 & Decaying cow dung & Bacillus altitudinis & 100 & KT381614 \\
\hline 3 & BS3 & Leaf compost & Bacillus cereus & 100 & KT356281 \\
\hline 4 & BS5 & River bank soil & Providencia rettgeri & 99 & KT381615 \\
\hline 5 & BS6 & Paper mill effluent & Bacillus amyloliquefaciens & 99 & KT381616 \\
\hline 6 & BS35 & Raw milk & Staphylococcus warneri & 99 & KX189101 \\
\hline 7 & BS36 & Moist soil & Bacillus pumilus & 100 & KT583750 \\
\hline 8 & BS37 & Moist soil & Bacillus safensis & 100 & KT354645 \\
\hline 9 & BS38 & Decaying agro-waste & Bacillus pumilus & 99 & KT962916 \\
\hline 10 & BS42 & Leaf compost & Bacillus subtilis & 99 & KT721566 \\
\hline 11 & BS131 & Moist soil & Bacillus pumilus & 100 & KT962917 \\
\hline
\end{tabular}

Table 5 Identification of potential xylanase producing fungi based on ITS gene sequence

\begin{tabular}{llllll}
\hline Sr. no. & Fungal strain & Isolation source & Identified as & Similarity (\%) & NCBI Accession no. \\
\hline 1 & ZGCL1 & Soil & Aspergillus niger & 99 & KT970477 \\
2 & ZGCL17 & Soil & Aspergillus flavus & 99 & KT970478 \\
3 & ZGCL23 & Saw dust & Fusarium oxysporum & 99 & KT970482 \\
4 & ZGCL25 & Soil & Penicillium digitatum & 99 & KT970480 \\
5 & ZGCL37 & Decaying wood & Trichoderma harzianum & 99 & KT970481 \\
6 & ZGCL43 & Soil & Aspergillus oryzae & 99 & KT970479 \\
\hline
\end{tabular}

\section{Quantification of xylanase production in cell free culture filtrate}

Cell free culture filtrate was assayed against DNS and color change in the mixture was observed at $553 \mathrm{~nm}$. The eleven bacterial and six fungal isolates that have significant xylanase productions were presented in Figs. 1 and 2. It showed that bacterial isolates BS131, 37 and 3 were the best three for xylanolytic index, i.e., 388.82, 385.26 and $354.17 \mathrm{IU} / \mathrm{ml}$, respectively. Whereas, among the fungal isolates, ZGCL17, ZGCL1 and ZGCL 25 presented relatively high xylanase indexes, i.e., 493.33, 419.33 and $391.82 \mathrm{IU} / \mathrm{ml}$. Isolation sources of the best xylanolytic microbial strains are listed in table. Specific activity observed and compared with the xylose standard curve (Tables 1,2).

Various assays were performed to estimate the production of different hydrolytic enzymes. The 17 potential isolates were subjected to test for their xylanase activity. Activities of xylanase, cellulase, $\beta$-xylosidase were estimated using appropriate protocols. The total protein content was determined by Bradford's method (Tables 1, 2) (Bradford 1976; Lachke 1988; Miller 1959; Zhang et al. 2011).

\section{Phenotypic characterization of competent xylanolytic microbes}

Results were recorded for bacterial \& fungal strains while using Bergey's manual and listed in table (Table 3). All microbial strains were identified using rRNA gene sequencing and their resemblance with the closest type strains are presented in Tables 4, 5. The best xylanolytic bacterial strain BS131 was identified as Bacillus pumilus and the best fungal producer ZGCL17 was identified as Aspergillus flavus.

\section{Discussion}

Out of the eleven bacterial and six fungal isolates that have been characterized for their cellulase free xylanase activity, Bacillus pumilus (BS131) and Bacillus safensis (BS37) are potential bacterial isolates due to their significant xylanase and minimum cellulase production. Aspergillus flavus (ZGCL17) and Aspergillus niger (ZGCL1) are the best cellulase free xylanase producers among the fungal 
isolates. These isolates have potential to be used in industrial processes especially suitable for paper and pulp industries.

Hence, isolation, screening and selection have facilitated the discovery of several cellulase free xylanase producers from a wide variety of environmental samples. The results indicate possible employment of such enzymes in a number of industrial processes with a decrease in current cost of bioconversion of lignocellulosic mass.

Acknowledgments The authors acknowledge the Higher Education Commission of Pakistan (HEC) and GCU Lahore for providing research facilities for current study.

\section{Compliance with ethical standards}

Conflict of interest The authors state that they have no conflict of interest in the publication of this article.

Open Access This article is distributed under the terms of the Creative Commons Attribution 4.0 International License (http:// creativecommons.org/licenses/by/4.0/), which permits unrestricted use, distribution, and reproduction in any medium, provided you give appropriate credit to the original author(s) and the source, provide a link to the Creative Commons license, and indicate if changes were made.

\section{References}

Bailey MJ, Biely P, Poutanen K (1992) Interlaboratory testing of methods for assay of xylanase activity. J Biotechnol 23:257-270

Biely P (1985) Microbial xylanolytic systems. Trends Biotechnol 3:186-290

Bradford MM (1976) A rapid and sensitive method for the quantification of microgram quantities of protein utilizing the principle of protein-dye binding. Anal Biochem 72:248-254

Brennan Y, Callen WN, Christoffersen L, Dupree P, Goubet F, Healey S, Hernandez M, Keller M, Li K, Palackal N, Sittenfeld A, Tamayo G, Wells S, Hazlewood GP, Mathur EJ, Short JM, Robertson DE, Steer BA (2004) Unusual microbial xylanases from insect guts. Appl Environ Microbiol 70:3609-3617

Collins T, Gerday C, Feller G (2005) Xylanases, xylanase families and extremophilic xylanases. FEMS Microbial Rev 29:3-23

Devillard E, Newbold CJ, Scott KP, Forano E, Wallace RJ, Jouany JP, Flint HJ (1999) Xylanase produced by the rumen anaerobic protozoan Polyplastron multivesiculatum shows close similarity with family 11 xylanase from Gram-positive bacteria. FEMS Microbiol Lett 181:145-152

Dodd D, Cann IKO (2009) Enzymatic deconstruction of xylan for biofuel production. Glob Chang Biol Bioenergy 1:2-17

Filho EXF (1998) Hemicellulase and biotechnology. In: Pandalai SG (ed) Recent research development in microbiology. Research Signpost, Trivandrum, pp 165-176
Frank JA, Reich CI, Sharma S, Weisbaum JS, Wilson BA, Olsen GJ (2008) Critical evaluation of two primers commonly used for amplification of bacterial 16S rRNA genes. Appl Environ. Microbiol 74(8):2461-2470

Fujita SI, Senda Y, Nakaguchi S, Hashimoto T (2001) Multiplex PCR using internal transcribed spacer 1 and 2 regions for rapid detection and identification of yeast strains. J Clin Microbiol 39:3617-3622

Ghose TK (1987) Measurement of cellulase activities. Pure Appl Chem 59(2):257-268

Haltrich D, Nidetzky B, Kulbe KD, Steiner W, Zupaneie S (1996) Production of fungal xylanases. Biores Technol 58:137-161

Kirk TK, Yang HH (1979) Partial delignification of unbleached kraft pulp with ligninolytic fungi. Biotechnol Lett 1:347-352

Lachke AH (1988) 1,4- $\beta$-d-xylan xylohydrolase of Sclerotium rolfsii. Meth Enzymol 160(C):679-684

Madlala AM, Bisson S, Singh S, Christov L (2001) Xylanase induced reduction of chlorine dioxide consumption during elemental chlorine free bleaching of different pulp types. Biotechnol Lett 23:345-351

Miller GL (1959) Use of dinitrosalisylic acid (DNS) for determination of reducing sugars. Anal Chem 31:426-428

Polizeli ML, Rizzatti AC, Monti R, Terenzi HF, Jorge JA, Amorim DS (2005) Xylanases from fungi: properties and industrial applications. Appl Microbiol Biotechnol 67(5):577-591

Roy I, Gupta A, Khare SK, Bisaria VS, Gupta MN (2003) Immobilization of xylan degrading enzymes from Melanocarpus albomyces IIS 68 on the smart polymer Eudragit L-100. Appl Micobiol Biotechnol 61:309-313

Samantha AK, Kolte AP, Senani S, Sridhar M, Jayapal N (2011) A simple and efficient diffusion technique for assay of endo- $\beta-1,4$ xylanase activity. Braz J Microbiol 42:1349-1353

Sambrook J, Russell DW (2001) Molecular Cloning: a Laboratory Manual, 3rd edn. Cold Spring Harbor Laboratory, Cold Spring Harbor

Schwien U, Schmidt E (1982) Improved degradation of monochloro phenols by a constructed strain. Appl Environ Microbiol 44(1):33-39

Sunna A, Antranikian G (1997) Xylanolytic enzymes from fungi and bacteria. Crit Rev Biotechnol 17(1):39-67

Viikari L, Ranua M, Kantelinen A, Linko M, Sundquist J (1986). Bleaching with enzymes. In: Biotechnology in the Pulp and paper industry. Proc. 3rd Int. Conf., Stockholm, pp 67-69

Wu YR, He J (2015) Characterization of a xylanase-producing Cellvibrio mixtus strain J3-8 and its genome analysis. Sci Rep. 5:1-11. doi:10.1038/srep10521

Yamura IK, Koga T, Matsumoto T, Kato T (1997) Purification and some properties of endo-1,4- $\beta$-D-xylanase from a fresh water mollusk, Pomacea insularus (de Ordigny). Biosc Biotech Biochem 61(4):615-620

Zhang F, Shi P, Bai Y, Luo H, Yuan T, Huang H, Yang P, Miao L, Yao B (2011) An acid and highly thermostable xylanase from Phialophora sp. G5. Appl Microbiol Biotechnol 89:1851-1858 